\title{
Optimasi Proses Kerangka Kerja: Penyesuaian Model Kualitas Perangkat Lunak Pada Aplikasi Bisnis Dengan Konsentrasi Pengembang
}

\author{
Arini R. Rosyadi ${ }^{1}$, Siti Rochimah ${ }^{2}$ \\ Program Studi Teknik Informatika, Fakultas Teknik, Universitas Muhammadiyah Malang \\ Jl. Raya Tlogomas No.246, Malang 65144, Jawa Timur \\ E-mail: ${ }^{1}$ arini.rosyadi@gmail.com, ${ }^{2}$ siti@if.its.ac.id
}

Masuk: 12 Juni 2014; Direvisi: 26 Juni 2014; Diterima: 8 Juli 2014

\begin{abstract}
Software in business activities have some unique characteristics. ISO 9126, which is general, is considered inadequate to cover all the unique characteristics of the particular software, one of which is business application. Customizing characteristics of a software quality model is intended to address the unique characteristics of specific software. User requirement and developer concentration become the objects of analysis in the application of framework process which aim to be able to customize software quality models that match the characteristics of bussiness applications. In testing, Cronbach Alpha coefficients are used to perform calculations on the survey result to determine the reliable value of the questionnaire. The results of the application of the framework shows that business applications have unique characteristics.
\end{abstract}

Keywords: Business application, ISO 9126, user requirement, developer concern, Cronbach Aplha coefficient.

Abstrak. Perangkat lunak dalam kegiatan bisnis memiliki beberapa keunikan karakteristik. Dan ISO 9126, yang bersifat general, dirasa tidak dapat mencakup seluruh karakteristik unik pada perangkat lunak tertentu, salah satunya adalah aplikasi bisnis. Penyesuaian karakteristik suatu model kualitas perangkat lunak ditujukan untuk mengatasi keunikan karakteristik perangkat lunak tertentu. Kebutuhan pengguna dan konsentrasi pengembang menjadi objek analisis dalam penerapan proses kerangka kerja dengan tujuan untuk dapat melakukan penyesuaian model kualitas perangkat lunak yang sesuai dengan karakteristik aplikasi bisnis. Pada pengujian, hasil survey dilakukan perhitungan dengan menggunakan koefisien Cronbach Alpha untuk mengetahui nilai reliabel dari kuisioner. Hasil penerapan proses kerangka kerja menunjukkan bahwa aplikasi bisnis memiliki karakteristik unik.

Kata Kunci: Aplikasi bisnis, ISO 9126, kebutuhan pengguna, konsentrasi pengembang, koefisien Cronbach Alpha

\section{Pendahuluan}

Dalam dunia bisnis, penggunaan perangkat lunak sangat membantu (Behkamal dkk, 2009: 599), dikarenakan beberapa layanan yang ada dalam aplikasi bisnis dirasa sangat bermanfaat. Dan juga beberapa keuntungan dalam penggunaan perangkat lunak yaitu dapat digunakan dalam banyak lingkungan yang berbeda-beda dan sifatnya yang mudah diakses di mana saja memudahkan pengguna untuk dapat melakukan aktifitas bisnis.

Keunikan dari karakteristik aplikasi bisnis adalah salah satu faktor penting dalam penilaian kualitas perangkat lunak (Suma dkk, 2013: 1480). Dari penelitian yang telah dilakukan sebelumnya (Behkamal dkk, 2009: 603), selain dari kualitas yang telah tercakup dalam beberapa model kualitas perangkat lunak, juga terdapat beberapa karakteristik unik lain yang belum tercakup.

Penyesuaian model kualitas perangkat lunak pada aplikasi bisnis diajukan oleh (Nabil dkk, 2011: 212). Peneliti mengajukan suatu proses kerangka kerja yang menggunakan kebutuhan pengguna untuk melakukan analisis. Selain itu, peneliti juga menggunakan ISO 9126 sebagai model kualitas perangkat lunak acuan. Akan tetapi penelitian lain (Sibisi \& Van 
Waveren, 2007: 1) mengemukakan bahwa dalam mengukur suatu kualitas perangkat lunak terdapat tiga perspektif yang harus diperhatikan yaitu pengguna, pengembang dan pemilik.

Fokus dari penelitian ini adalah melibatkan perspektif pengembang suatu perangkat lunak dalam proses kerangka kerja (Nabil dkk, 2011: 214) untuk mendapatkan karakteristik unik dari aplikasi bisnis. Sehingga penyesuaian model kualitas perangkat lunak dapat dilakukan terhadap aplikasi bisnis.

Makalah ini terbagi menjadi sub-bab pembahasan. Pada sub-bab dua diberikan paparan atas penelitian-penelitian yang telah dilakukan sebelumnya. Selanjutnya penjelasan proses kerangka kerja usulan dipaparkan pada sub-bab empat. Dan sub-bab lima menjelaskan proses pengujian dari penggunaan proses kerangka kerja yang diusulkan dengan menggunakan beberapa dataset serta hasil dari pengujian yang telah dilakukan. Serta memberikan hasil yang didapatkan. Selanjutnya pada sub-bab enam, dipaparkan hasil analisis dari hasil survei yang telah dilakukan. Dan terakhir, sub-bab tujuh diberikan kesimpulan dari penelitian yang telah dilakukan.

\section{Tinjauan Pustaka \\ 2.1. Penelitian Sebelumnya}

Dalam penelitiannya (Behkamal dkk, 2009: 601) Behshid melakukan penyesuaian karakteristik dari Aplikasi B2B (Bisnis ke Bisnis) pada model kualitas perangkat lunak ISO 9126. Peneliti melakukan penyesuaian hingga tingkatan kedua dari ISO 9126. Pada proses penyesuaian, peneliti menggali suatu karakteristik dari Aplikasi B2B dengan melakukan suatu survei atau kuisioner terhadap beberapa responden yang merupakan sistem pakar.

Penggalian karakteristik dilakukan untuk mendapatkan karakteristik yang belum tercakup dalam model kualitas perangkat lunak yang telah ada. Dari survei yang dilakukan, peneliti mendapatkan fakta bahwa beberapa karakteristik unik dari aplikasi B2B adalah diantaranya customizability, traceability, navigability, avalaibility.

Selanjutnya penelitian (Suma dkk, 2013: 1480) melakukan penyesuaian faktor kualitas dari suatu perangkat lunak, dengan harapan untuk meningkatkan kualitas dari perangkat lunak sehingga penggunaan perangkat lunak dalam kegiatan bisnis menjadi lebih optimal. Dalam penelitiannya, peneliti tidak menggunakan acuan model kualitas perangkat lunak untuk melakukan penyesuaian. Akan tetapi peneliti melakukan penyesuaian faktor kualitas dari beberapa sudut pandang perangkat lunak selanjutnya mengidentifikasi faktor-faktor kualitas tersebut untuk menentukan kualitas dari sistem aplikasi bisnis.

Dalam proses penyesuaian, peneliti mengemukakan bahwa perbedaan dari tingkat kompleksitas suatu aplikasi bisnis akan menghasilkan faktor kualitas yang berbeda pula. Sehingga peneliti melakukan suatu pengamatan terhadap tingkat kompleksitas terhadap perangkat lunak dari jenis perusahaan yang berbeda. Diantaranya adalah tingkat kompleksitas dari biaya perusahaan dan projek yang dikembangkan. Sehingga dari hasil pengamatan tersebut, peneliti menentukan faktor kualitas utama dari masing-masing jenis perusahaan dan selanjutnya melakukan penyesuaian terhadap model kualitas perangkat lunak.

Penelitian berikutnya (Sibisi \& Van Waveren, 2007: 2) bertujuan untuk mengajukan suatu kerangka kerja yang digunakan dalam pengukuran kualitas suatu perangkat lunak. Alur proses kerangka kerja yang diusulkan ada di Gambar 1. Selain itu, tujuan dari penelitian ini adalah memaksimalkan tercapainya tujuan bisnis. Dalam penelitiannya, penulis menjelaskan bahwa selama ini kualitas perangkat lunak diukur dengan menggunakan pendekatan secara kuantitatif dan mengesampingkan pengukuran yang dilakukan berdasarkan pada perangkat lunak yang dihasilkan. Maka penulis mengajukan suatu kerangka kerja yang dapat digunakan oleh suatu perusahaan pengembang untuk melakukan penyesuaian model kualitas perangkat lunak sesuai dengan jenis perangkat lunak yang dikembangkan. Dalam metodenya penulis menerapkan pendekatan GQM (Goal-Question-Metrics) yang mendapatkan keluaran berupa model kualitas perangkat lunak yang telah disesuaikan.

Dalam penelitian ini, kelemahan yang dimiliki adalah peneliti hanya mengutamakan kebutuhan pengguna dan mengesampingkan perspektif pemangku kebutuhan yang lain. 
Sedangkan dalam aplikasi bisnis yang bertujuan dalam dunia bisnis, tujuan dan kebutuhan dari sudut pandang pengembang dan juga pemilik harus diperhitungkan (Nabil dkk, 2011: 213).

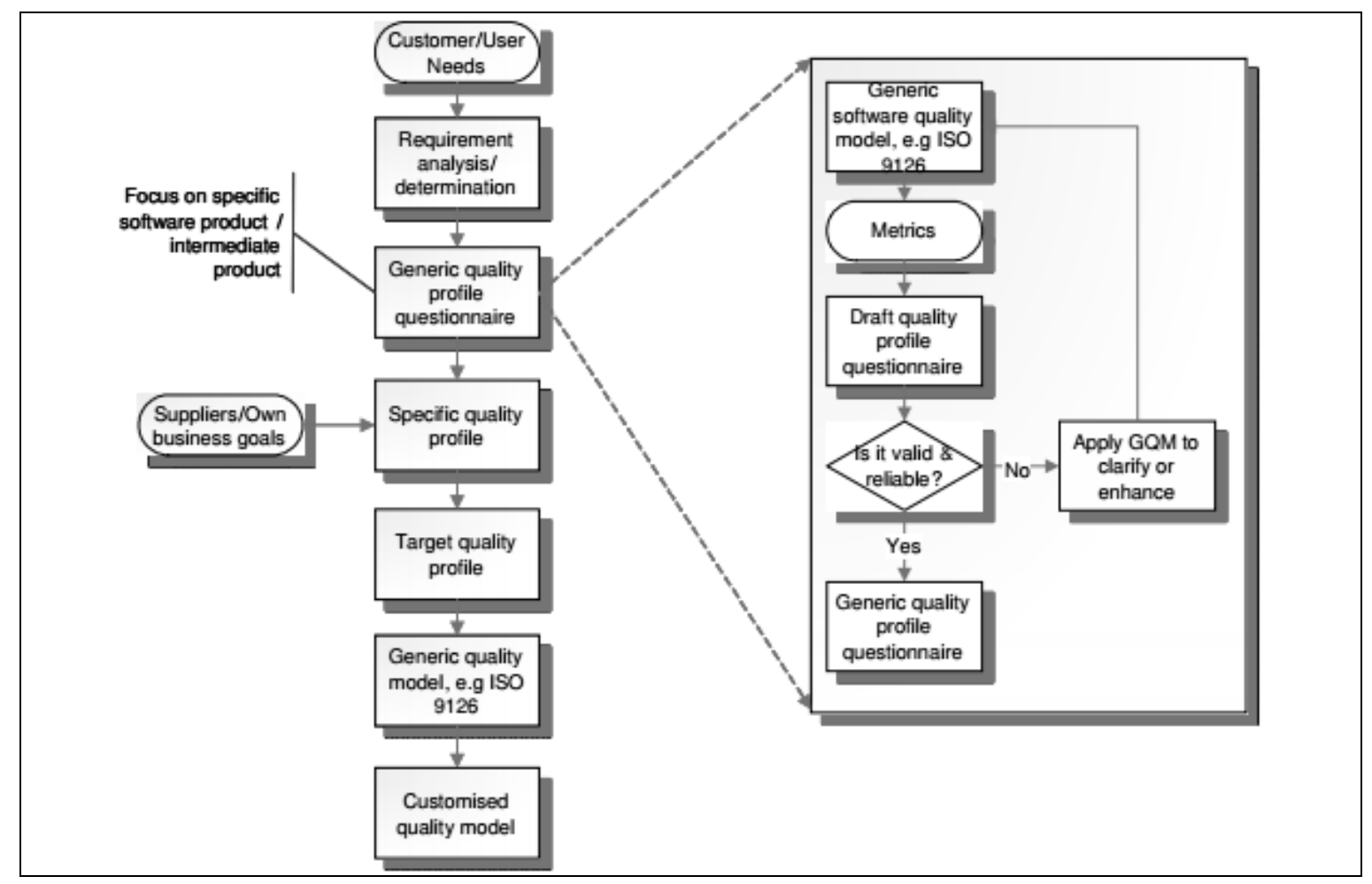

Gambar 1. Alur Proses Kerangka Kerja Penyesuaian Model Kualitas Perangkat Lunak (Sibisi \& Van Waveren, 2007: 4)

\subsection{Model Kualitas Perangkat Lunak ISO 9126}

Model kualitas perangkat lunak ISO dikembangkan oleh organisasi besar ISO. Model kualitas ISO 9126 digunakan oleh banyak peusahaan pengembang. Hal ini disebabkan, ISO 9126 memiliki karakteristik kualitas lebih lengkap dibandingkan dengan model kualitas perangkat lunak yang lain (Behkamal dkk, 2009: 600). Selain itu, ISO 9126 memiliki enam karakteristik dan 27 sub-karakteristik yang dapat digunakan pada banyak perusahaan perangkat lunak (Al-Qutaish, 2009: 275).

Model kualitas ISO 9126 sering disebut dengan six quality characteristic ini memiliki enam karakteristik utama, yaitu Functionality, Reliability, Usability, Efficiency, Maintainability dan Portability (Parwita \& Ayu Luh, 2012: 92). Dan masing-masing karakteristik memiliki sub karakteristik. Selain itu karakteristik dalam ISO 9126 terbagi menjadi kualitas internal, kualitas eksternal dan juga kualitas selama penggunaan perangkat lunak (Sibisi \& Van Waveren, 2007: $1)$.

Keutamaan dalam penggunaan ISO 9126 sebagai model kualitas perangkat lunak adalah ISO memiliki beberapa kelebihan diantaranya, sifatnya yang berstruktur hierarkikal, bersifat komprehensif dan juga hubungan antara level-level karakteristiknya yang one-to-many (Behkamal dkk, 2009: 600).

\section{Metode yang Diusulkan}

Berdasarkan pada penelitian-penelitian yang disebutkan dalam sub-bab sebelumnya, penelitian ini mengajukan suatu proses kerangka kerja yang bertujuan untuk melakukan penyesuaian karakteristik model kualitas perangkat lunak yang sesuai dengan aplikasi bisnis yang dikembangkan. Penelitian ini mengkombinasikan dua teori yang dikemukan pada penelitian yang diulas pada sub-bab sebelumnya. Penelitian ini mengajukan suatu proses kerangka kerja yang mengacu pada penelitian (Sibisi \& Van Waveren, 2007: 2). Dan juga 
penelitian ini menjadikan penelitian (Nabil dkk, 2011: 213) yang mempertimbangkan perspektif pengembang dalam proses penyesuaian kualitas model aplikasi bisnis.

Proses kerangka kerja penyesuaian model kualitas perangkat lunak dilakukan dengan mengkombinasikan metode penyesuaian yang telah dilakukan oleh peneliti (Sibisi \& Van Waveren, 2007: 4) dan (Nabil dkk, 2011: 213), yaitu membuat suatu skema proses penyesuaian yang bermula dari adanya kebutuhan pengguna yang menjadi suatu model kualitas perangkat lunak yang sesuai dengan karakteristik dari aplikasi bisnis yang dikembangkan (Sibisi \& Van Waveren, 2007: 4). Selain itu, penelitian ini juga melibatkan perspektif pengembang dalam menganalisis kualitas suatu aplikasi bisnis. Dalam (Nabil dkk, 2011: 214), peneliti memperhatikan tiga sudut pandang yang berpengaruh terhadap kualitas aplikasi bisnis, yaitu pengguna (visitor), pengembang (developer) dan juga pemilik (owner) dari aplikasi bisnis tersebut. Dalam penelitian ini, konsentrasi pengembang menjadi salah satu faktor penting dalam pembuatan kuisioner. Sehingga, dalam penelitian ini terdapat dua sudut pandang yang digunakan untuk melakukan penyesuaian model kualitas perangkat lunak terhadap aplikasi bisnis.

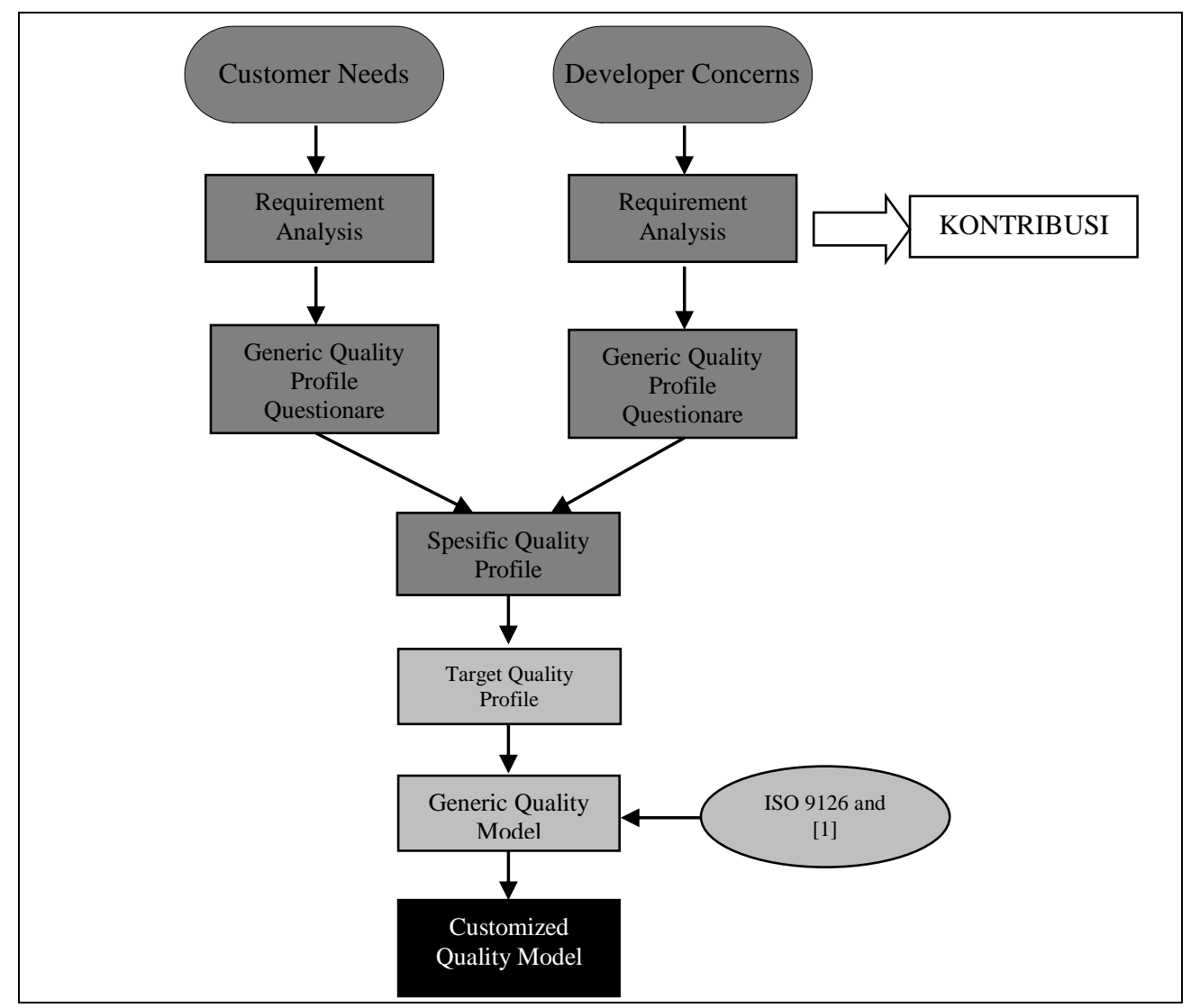

Gambar 2. Alur Proses Kerangka Kerja yang Diajukan

Secara jelas, proses kerangka kerja yang diusulkan diberikan pada Gambar 2. Sesuai dengan alur yang digunakan pada (Sibisi \& Van Waveren, 2007: 4), terdapat empat tahapan dalam proses kerangka kerja ini. Tahapan pertama adalah tahap identifikasi kebutuhan terhadap perspektif pemangku kebutuhan, pada tahapan ini dibuat pernyataan - pernyataan sebagai bahan survei (Sibisi \& Van Waveren, 2007: 4), yaitu setiap pernyataan yang dibuat merepresentasikan tujuan yang diharapkan. Pada tahapan ini, peneliti melibatkan dua pemangku kebutuhan, yaitu pengguna dan pengembang. Pernyataan kedua pemangku kebutuhan tersebut adalah berbeda. Pernyataan pengguna berkaitan dengan kebutuhan pengguna terkait tujuan aplikasi bisnis tersebut sedangkan pengembang berkaitan dengan hal - hal yang menjadi fokus pengembang dalam proses pengembangan aplikasi bisnis. 
Tahapan kedua adalah melakukan spesifikasi tujuan dari dikembangkannya aplikasi bisnis yang bersangkutan. Dalam proses spesifikasi ini, hasil survei terhadap pengguna memiliki peran yang penting. Pengguna memberikan penilaian terhadap aplikasi bisnis yang digunakan. Dan hasil survei terhadap pengembang memberikan penilaian terhadap kualitas selama proses pengembangan aplikasi bisnis. Sehingga tahapan ini mendapatkan tujuan yang lebih spesifik dari aplikasi bisnis yang dikembangkan.

Tahapan ketiga adalah melakukan penentuan dari tujuan kualitas berdasarkan hasil tahapan ketiga. Selanjutnya simple matching dilakukan antara hasil tahapan ketiga dengan model kualitas perangkat lunak yang menjadi acuan. Dalam penelitian ini, ISO 9126 digunakan sebagai model kualitas perangkat lunak acuan. Tahapan keempat adalah penyesuaian model kualitas perangkat lunak. Penyesuaian dilakukan berdasarkan hasil dari tahapan-tahapan sebelumnya. Selanjutnya model kualitas perangkat lunak yang telah disesuaikan diujikan terhadap aplikasi bisnis yang dikembangkan.

\section{Skenario dan Hasil Pengujian 4.1. Skenario Pengujian}

Proses pengujian melibatkan dua aplikasi bisnis. Aplikasi bisnis pertama merupakan perangkat lunak yang menjalankan sistem jual beli beberapa produk. Dengan produk ini pembeli dapat berbelanja menggunakan aplikasi bisnis tersebut. Sedangkan untuk aplikasi bisnis kedua merupakan suatu sistem yang bergerak dalam pembayaran on-line yang melibatkan banyak pengguna di dalamnya. Kedua aplikasi bisnis tersebut merupakan aplikasi bisnis berbasis web yang dikembangkan dengan menggunakan bahasa pemrograman PHP (Hypertext Preprocessor).

Pengujian ini menerapkan kerangka kerja yang diusulkan kepada kedua aplikasi bisnis sebagai proses pengujian kualitas perangkat lunak. Sehingga sesuai dengan proses kerangka kerja yang diajukan, pengujian ini juga terdapat empat tahapan.

Tahapan pertama adalah melakukan survei terhadap pengguna dan pengembang dari aplikasi bisnis tersebut. Survei untuk terhadap responden dilakukan berdasarkan pada penelitian (Sibisi \& Van Waveren, 2007: 4) yang menyatakan bahwa survei merupakan salah satu metode yang efektif untuk mendapatkan ekspektasi pengguna suatu aplikasi. Hal ini dikarenakan dengan kuisioner yang dibuat berdasarkan dokumen kebutuhan pengguna maka didapatkan penilaian secara objektif terhadap aplikasi bisnis. Kuisioner dikirimkan pada 12 responden yang merupakan pengguna dan 5 responden yang merupakan pengembang pada masing-masing aplikasi bisnis. Penentuan jumlah responden pengguna didasarkan pada intensitas pengguna dalam melakukan transaksi bisnis. 12 responden pengguna merupakan pengguna teraktif dalam melakukan transaksi. Sehingga dapat diasumsikan bahwa responden pengguna tersebut mengenali dengan baik menu-menu yang dimiliki oleh aplikasi bisnis yang digunakan.

Kuisioner terhadap responden pengguna dibuat berdasarkan pada daftar kebutuhan dari aplikasi bisnis yang dibuat oleh pemilik aplikasi bisnis. Sedangkan kuisioner terhadap responden pengembang menggunakan acuan karakteristik dari perspektif pengembang berdasarkan penelitian (Nabil dkk, 2011: 214). Pada perspektif pengembang terdapat tiga karakteristik yang tercakup yaitu maintainability, portability dan reusability (Gambar 3).

Setiap responden memberikan penilaian terhadap setiap pernyataan yang diberikan. Responden memberikan salah satu kategori penilaian dari lima kategori yang diberikan. Peniliaian hasil kuisioner dibagi menjadi lima kategori yang masing-masing memiliki nilai. (1) Sangat Tidak Setuju (STS), (2) Tidak Setuju (TS), (3) Kurang Setuju (KS), (4) Setuju (S), dan (5) Sangat Setuju (SS).

Tahapan kedua, hasil survei dianalisis untuk dapat disesuaikan dengan kebutuhan yang telah didapatkan sebelumnya. Tahapan ketiga, hasil analisis kuisioner dicocokkan dengan model kualitas perangkat lunak yang menjadi acuan pada penelitian ini. Tahapan keempat, hasil pencocokan yang didapatkan pada tahapan sebelumnya dilakukan penyesuaian untuk menemukan karakteristik dari aplikasi bisnis yang digunakan. Keluaran dari tahapan ini adalah karakteristik-karakteristik yang sesuai dengan aplikasi bisnis yang diujikan. 


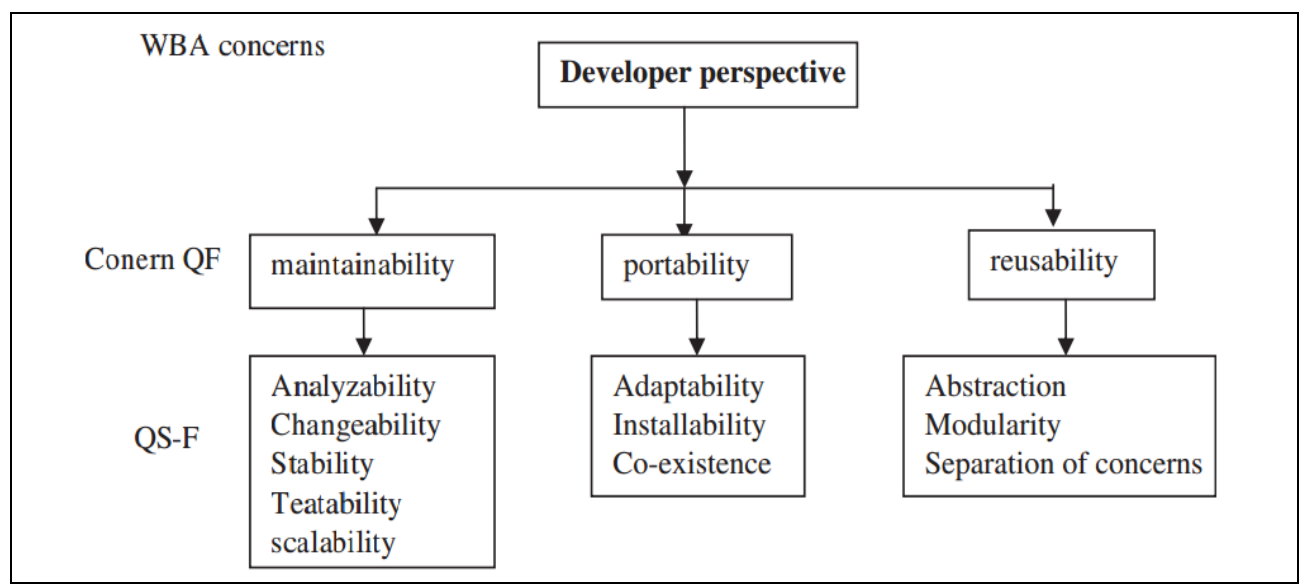

Gambar 3. Karakteristik dalam Sudut Pandang Pengembang (Nabil dkk, 2011: 214)

\subsection{Hasil Pengujian}

Dari pengujian yang diulas pada sub-bab sebelumnya, didapatkan beberapa hasil yang dipaparkan pada sub-bab ini. Tahapan pertama adalah melakukan survei dengan responden para pengguna dan juga pengembang. Dari 12 orang pengguna pada masing-masing aplikasi bisnis tidak seluruhnya memberikan respon. Pada aplikasi bisnis pertama didapatkan 9 respon sedangkan pada aplikasi bisnis kedua didapatkan 7 respon. Sedangkan dari 5 pengembang dari masing-masing aplikasi bisnis, 4 respon didapatkan dari aplikasi bisnis pertama dan 3 respon dari aplikasi bisnis kedua. Kuisioner yang dibuat masing-masing pernyataan merepresentasikan dari karakteristik kualitas yang diujikan.

Tabel 1. Penilaian Kuisioner Pengguna Terhadap Aplikasi Bisnis I

\begin{tabular}{|c|c|c|c|c|c|c|c|c|c|c|}
\hline \multirow{2}{*}{ Pernyataan } & \multicolumn{9}{|c|}{ Pengguna } & \multirow{2}{*}{ Total } \\
\hline & 1 & 2 & 3 & 4 & 5 & 6 & 7 & 8 & 9 & \\
\hline 1 & 5 & 5 & 4 & 5 & 5 & 3 & 4 & 4 & 5 & 40 \\
\hline 2 & 4 & 4 & 4 & 3 & 4 & 3 & 4 & 4 & 5 & 35 \\
\hline 3 & 5 & 4 & 4 & 3 & 3 & 3 & 4 & 5 & 5 & 36 \\
\hline 4 & 5 & 5 & 5 & 5 & 5 & 5 & 5 & 5 & 5 & 45 \\
\hline 5 & 4 & 5 & 4 & 3 & 4 & 3 & 4 & 4 & 5 & 36 \\
\hline 6 & 4 & 4 & 4 & 4 & 4 & 4 & 4 & 4 & 4 & 36 \\
\hline 7 & 4 & 5 & 4 & 3 & 4 & 3 & 4 & 4 & 5 & 36 \\
\hline 8 & 4 & 3 & 4 & 4 & 3 & 3 & 4 & 4 & 4 & 33 \\
\hline 9 & 5 & 4 & 4 & 4 & 3 & 4 & 4 & 5 & 5 & 38 \\
\hline 10 & 5 & 5 & 3 & 4 & 4 & 4 & 4 & 5 & 5 & 39 \\
\hline 11 & 5 & 5 & 4 & 4 & 4 & 4 & 4 & 4 & 4 & 38 \\
\hline 12 & 5 & 5 & 3 & 4 & 4 & 4 & 4 & 5 & 5 & 39 \\
\hline 13 & 4 & 4 & 3 & 4 & 3 & 3 & 4 & 5 & 5 & 35 \\
\hline 14 & 4 & 4 & 3 & 4 & 3 & 3 & 4 & 5 & 5 & 35 \\
\hline
\end{tabular}

Tabel 2. Penilaian Kuisioner Pengembang Terhadap Aplikasi Bisnis I

\begin{tabular}{cccccc}
\hline \multirow{2}{*}{ Pernyataan } & \multicolumn{4}{c}{ Pengembang } & \multirow{2}{*}{ Total } \\
\cline { 2 - 5 } & 1 & 2 & 3 & 4 & \\
\hline 1 & 4 & 4 & 3 & 4 & 15 \\
\hline 2 & 4 & 4 & 3 & 4 & 15 \\
\hline 3 & 3 & 4 & 4 & 4 & 15 \\
\hline 4 & 4 & 3 & 3 & 5 & 19 \\
\hline 5 & 3 & 3 & 3 & 4 & 13 \\
\hline 6 & 3 & 3 & 3 & 4 & 13 \\
\hline 7 & 4 & 3 & 3 & 3 & 13 \\
\hline 8 & 4 & 4 & 4 & 4 & 16 \\
\hline 9 & 3 & 3 & 4 & 4 & 14 \\
\hline 10 & 4 & 4 & 4 & 4 & 16 \\
\hline 11 & 4 & 4 & 4 & 4 & 16 \\
\hline
\end{tabular}

Tabel 1 merupakan penilaian dari hasil kuisioner yang dilakukan pada aplikasi bisnis pertama. Dan Pada Tabel 2 dipaparkan hasil penilaian kuisioner terhadap pengembang dari 
aplikasi bisnis kedua. Sedangkan pada Tabel 3 dipaparkan hasil penilaian kuisioner terhadap pengguna dari aplikasi bisnis kedua. Dan pada Tabel 4 dipaparkan hasil penilaian kuisioner terhadap pengembang dari aplikasi bisnis kedua.

Tabel 3. Penilaian Kuisioner Pengguna Terhadap Aplikasi Bisnis II

\begin{tabular}{ccccccccc}
\hline \multirow{2}{*}{ Pernyataan } & \multicolumn{7}{c}{ Pengguna } & \multirow{2}{*}{ Total } \\
\cline { 2 - 7 } & 1 & 2 & 3 & 4 & 5 & 6 & 7 & \\
\hline 1 & 5 & 5 & 3 & 4 & 5 & 4 & 4 & 30 \\
\hline 2 & 3 & 3 & 3 & 4 & 5 & 4 & 4 & 26 \\
\hline 3 & 5 & 5 & 5 & 4 & 5 & 5 & 4 & 33 \\
\hline 4 & 5 & 5 & 5 & 4 & 5 & 5 & 5 & 34 \\
\hline 5 & 4 & 5 & 5 & 4 & 4 & 4 & 5 & 31 \\
\hline 6 & 4 & 5 & 4 & 4 & 5 & 4 & 4 & 30 \\
\hline 7 & 4 & 4 & 4 & 4 & 4 & 4 & 5 & 29 \\
\hline 8 & 4 & 3 & 4 & 4 & 4 & 4 & 4 & 27 \\
\hline 9 & 5 & 5 & 4 & 4 & 5 & 5 & 5 & 33 \\
\hline 10 & 5 & 5 & 4 & 4 & 5 & 5 & 5 & 33 \\
\hline 11 & 4 & 4 & 4 & 4 & 5 & 5 & 5 & 31 \\
\hline 12 & 5 & 5 & 4 & 4 & 5 & 5 & 4 & 32 \\
\hline 13 & 4 & 5 & 4 & 4 & 4 & 4 & 4 & 29 \\
\hline 14 & 4 & 5 & 4 & 4 & 4 & 4 & 4 & 29 \\
\hline 15 & 4 & 4 & 4 & 4 & 5 & 4 & 4 & 29 \\
\hline
\end{tabular}

Tabel 4. Penilaian Kuisioner Pengembang Terhadap Aplikasi Bisnis II

\begin{tabular}{ccccc}
\hline \multirow{2}{*}{ Pernyataan } & \multicolumn{3}{c}{ Pengembang } & \multirow{2}{*}{ Total } \\
\cline { 2 - 4 } & 1 & 2 & 3 & \\
\hline 1 & 5 & 5 & 5 & 15 \\
\hline 2 & 5 & 4 & 5 & 14 \\
\hline 3 & 4 & 4 & 5 & 13 \\
\hline 4 & 5 & 4 & 5 & 14 \\
\hline 5 & 4 & 4 & 4 & 12 \\
\hline 6 & 4 & 4 & 4 & 12 \\
\hline 7 & 4 & 4 & 4 & 12 \\
\hline 8 & 4 & 4 & 4 & 12 \\
\hline 9 & 4 & 4 & 4 & 12 \\
\hline 10 & 4 & 4 & 4 & 12 \\
\hline 11 & 4 & 4 & 4 & 12 \\
\hline
\end{tabular}

\section{Diskusi}

Kuisioner yang dilakukan terhadap pengguna didasarkan pada kebutuhan pengguna, mencerminkan beberapa karakteristik yang dimiliki oleh model ISO 9126, yaitu functionality, reliability, efficiency, usability, portability dan traceability. Dapat terlihat disini, bahwa terdapat karakteristik ISO 9126 yang tidak menjadi karakteristik yang dilibatkan. Akan tetapi juga terdapat karakteristik lain yang tidak termasuk dalam model ISO 9126, yakni traceability. Sedangkan kuisioner yang dilakukan terhadap pengembang, merepresentasikan subkarakteristik yang menjadi perhatian pengembang dalam melakukan pengembangan terhadap aplikasi bisnis, yaitu maintainability dinyatakan pada pernyataan 1 sampai dengan 5 , portability dinyatakan pada pernyataan 6 sampai dengan 8, dan reusability dinyatakan pada pernyataan 9 sampai dengan 11.

Pada Tabel 5 dan Tabel 6 diberikan perhitungan secara statistik yang mencakup nilai total, jumlah item, minimal (min), maksimal (max), nilai tengah (median) dan juga rata-rata (mean) dari tiap-tiap karakteristik untuk mengetahui takaran keterlibatan karakteristik tersebut dalam model pengujian aplikasi bisnis. Tabel 5 memberikan keterangan dari hasil survei yang dilakukan pada aplikasi bisnis pertama. Dari kuisioner yang dibuat terlihat bahwa terdapat beberapa karakteristik yang terkandung dalam kebutuhan pengguna yakni Usability, Portability, Maintainability, Efficiency, Reliability dan Functionality. Tabel 5 memberikan hasil statistik dari masing-masing karakteristik yang terdapat pada kuisioner yang dibuat. Nilai total merupakan jumlah penilaian yang didapatkan dari masing-masing karakteristik. Selanjutnya nilai item adalah banyaknya pernyataan pada kuisioner yang dibuat dan merepresentasikan karakteristik yang ditujukan. 
Tabel 6 merupakan hasil penilaian dari aplikasi bisnis kedua. Pada tabel ini terlihat bahwa adanya karakteristik baru yang tidak dimiliki oleh aplikasi bisnis yang pertama. Yakni karakteristik Traceability. Pada karakteristik ini, terlihat bahwa item yang terdapat dalam kuisioner pun hanya ada satu item. Akan tetapi nilai yang diberikan oleh para pengguna cukup besar, sehingga karakteristik ini dikatakan cukup penting untuk dimasukkan menjadi salah satu karakteristik pengujian dalam model kualitas perangkat lunak.

Hasil analisis penilaian survei yang sesuai dengan proses kerangka kerja yang diusulkan yang dilakukan pada aplikasi bisnis pertama dan kedua diberikan pada Gambar 4. Sedangkan hasil penilaian survei yang sesuai dengan proses kerangka kerja acuan diberikan pada Gambar 5. Pada kedua gambar tersebut merepresentasikan diagram yang menunjukkan nilai dari masingmasing karakteristik sesuai dengan nilai rata-rata yang didapatkan. Kedua gambar tersebut menunjukkan bahwa terdapat perbedaan karakteristik yang muncul. Gambar 4 memiliki karakteristik yang tidak dimiliki oleh Gambar 5. Karakteristik yang tidak muncul merupakan karateristik yang terdapat pada survei yang dilakukan terhadap pengembang. Data ini juga dapat dilihat pada Tabel 7 dan Tabel 8.

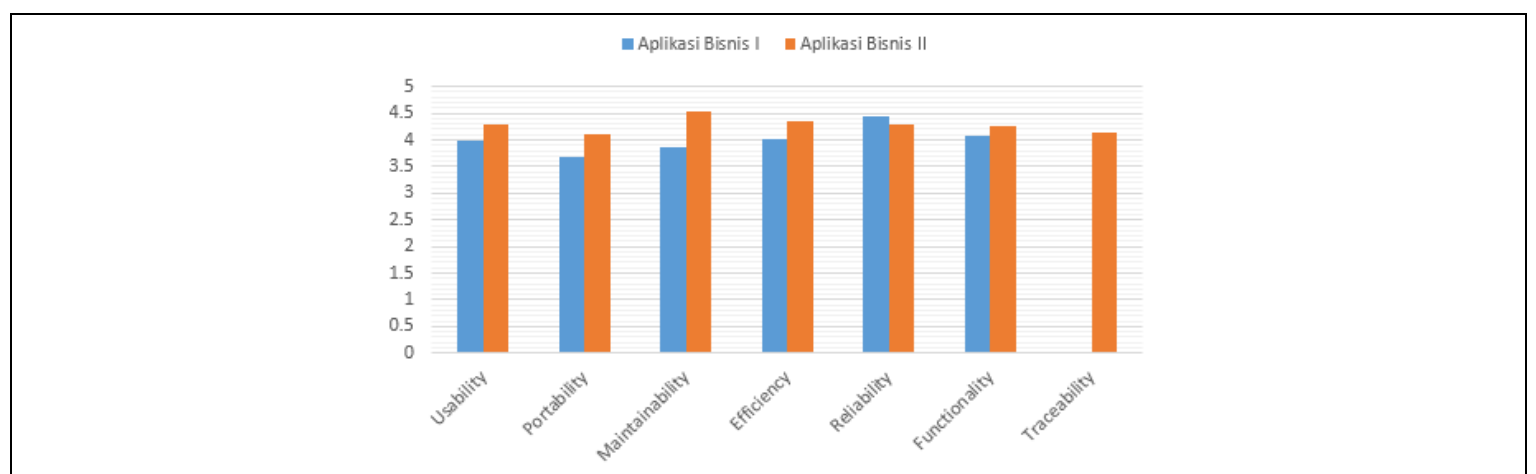

Gambar 4. Karakter Kualitas Hasil Proses Kerangka Kerja yang Diusulkan pada Aplikasi Bisnis I dan Aplikasi Bisnis II

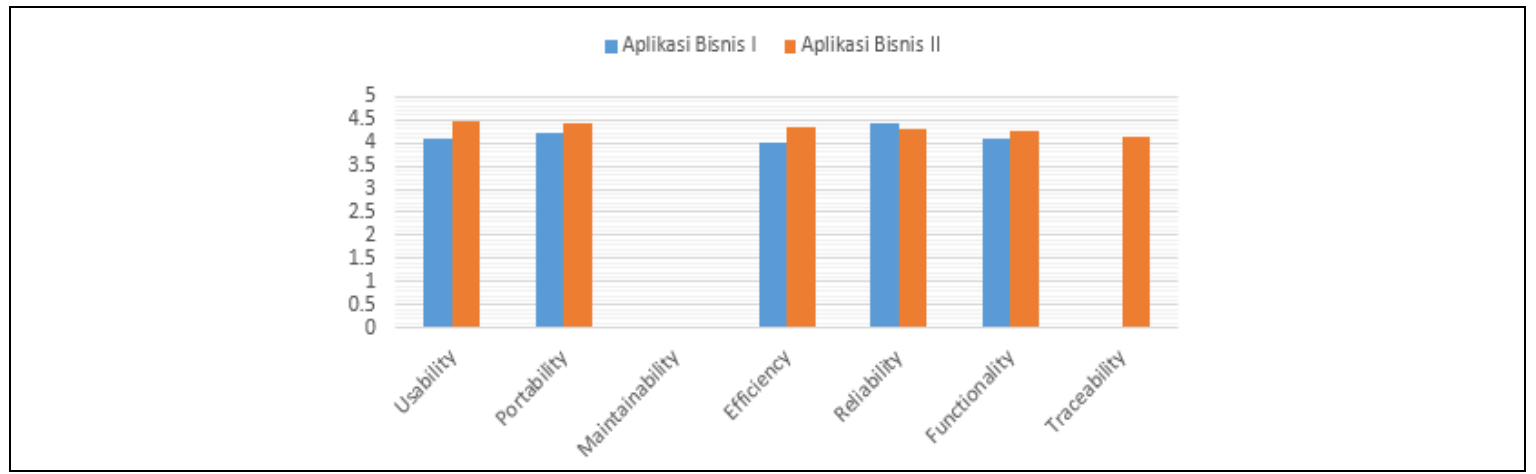

Gambar 5. Karakter Kualitas Hasil Proses Kerangka Kerja Acuan pada Aplikasi Bisnis I dan Aplikasi Bisnis II

Pada Gambar 4 terlihat bahwa pada aplikasi bisnis pertama memiliki nilai kualitas yang tinggi pada karakteristik Reliability. Jika diperhatikan pada jumlah item pernyataan yang merepresentasikan karakteristik Reliability, tidak memiliki banyak item, yaitu 2 item, akan tetapi penilaian dari responden sangat besar, yaitu nilai 5, jika dibandingkan dengan karakteristik yang lain. Sehingga rata-rata yang dihasilkan dari penilaian memiliki nilai yang tinggi pula. Dan pada aplikasi bisnis kedua, karakteristik yang memiliki nilai tertinggi adalah Maintainability. Jika diperhatikan pada kuisioner yang telah dibuat, karakteristik ini hanya ada pada survei yang dilakukan terhadap pengembang. Akan tetapi, penilaian yang tinggi yang diberikan oleh responden memberikan nilai rata-rata yang tinggi pula. Sehingga dibandingkan dengan karakteristik yang lain, karakteristik ini memiliki penilaian yang tinggi. 
Tabel 5. Deskripsi Statistik Proses Kerangka Kerja Usulan pada Aplikasi Bisnis I

\begin{tabular}{|c|c|c|c|c|c|c|}
\hline \multicolumn{7}{|c|}{ APLIKASI BISNIS I } \\
\hline Part & Usability & Portability & Maintainability & Efficiency & Reliability & Functionality \\
\hline Total & 31.944 & 14.722 & 19.25 & 8 & 8.888 & 16.333 \\
\hline Item & 8 & 4 & 5 & 2 & 2 & 4 \\
\hline Min & 3.5 & 3.25 & 3.25 & 4 & 3.888 & 3.666 \\
\hline $\operatorname{Max}$ & 4.333 & 4.222 & 4.75 & 4 & 5 & 4.444 \\
\hline Mean & 3.993 & 3.680 & 3.85 & 4 & 4.444 & 4.083 \\
\hline Median & 4 & 3.625 & 3.75 & 4 & 4.444 & 4.111 \\
\hline
\end{tabular}

Tabel 6. Deskripsi Statistik Proses Kerangka Kerja Usulan pada Aplikasi Bisnis II

\begin{tabular}{lccccccc}
\hline \multicolumn{1}{c}{ Part } & Usability & Portability & Maintainability & Efficiency & Reliability & Functionality & Traceability \\
\hline Total & 34.285 & 16.428 & 22.666 & 8.714 & 8.571 & 17 & 4.142 \\
\hline Item & 8 & 4 & 5 & 2 & 2 & 4 & 1 \\
\hline Min & 4 & 4 & 4 & 4.285 & 3.714 & 3.857 & 4.142 \\
\hline Max & 4.714 & 4.428 & 5 & 4.428 & 4.857 & 4.714 & 4.142 \\
\hline Mean & 4.285 & 4.107 & 4.533 & 4.357 & 4.285 & 4.25 & 4.142 \\
\hline Median & 4.142 & 4 & 4.666 & 4.357 & 4.285 & 4.214 & 4.142 \\
\hline
\end{tabular}

Tabel 7. Deskripsi Statistik Proses Kerangka Kerja Acuan pada Aplikasi Bisnis I

\begin{tabular}{lcccccc}
\hline \multicolumn{1}{c}{ Part } & Usability & Portability & Maintainability & Efficiency & Reliability & Functionality \\
\hline Total & 20.444 & 4.222 & - & 8 & 8.888 & 16.333 \\
\hline Item & 5 & 1 & - & 2 & 2 & 4 \\
\hline Min & 3.5 & 4.222 & - & 4 & 3.888 & 3.666 \\
\hline Max & 4.333 & 4.222 & - & 4 & 5 & 4.444 \\
\hline Mean & 4.088 & 4.222 & - & 4 & 4.444 & 4.083 \\
\hline Median & 4.333 & 4.222 & - & 4 & 4.444 & 4.111 \\
\hline
\end{tabular}

Tabel 8. Deskripsi Statistik Proses Kerangka Kerja Acuan pada Aplikasi Bisnis II

\begin{tabular}{lccccccc}
\hline \multicolumn{1}{c}{ Part } & Usability & Portability & Maintainability & Efficiency & Reliability & Functionality & Traceability \\
\hline Total & 22.285 & 4.428 & - & 8.714 & 8.571 & 17 & 4.142 \\
\hline Item & 5 & 1 & - & 2 & 2 & 4 & 1 \\
\hline Min & 4.142 & 4.428 & - & 4.285 & 3.714 & 3.857 & 4.142 \\
\hline Max & 4.714 & 4.428 & - & 4.428 & 4.857 & 4.714 & 4.142 \\
\hline Mean & 4.457 & 4.428 & - & 4.357 & 4.285 & 4.25 & 4.142 \\
\hline Median & 4.571 & 4.428 & - & 4.357 & 4.285 & 4.214 & 4.142 \\
\hline
\end{tabular}

Tabel 9. Analisis Nilai Reliabel (Cronbach Alpha)

\begin{tabular}{|c|c|c|c|c|c|}
\hline \multirow{3}{*}{ Item Terevaluasi } & \multirow{3}{*}{$\begin{array}{l}\text { Total Item } \\
\text { Pernyataan }\end{array}$} & \multicolumn{4}{|c|}{ Internal Consistency Reliability Coefficient } \\
\hline & & \multicolumn{2}{|c|}{ APLIKASI BISNIS I } & \multicolumn{2}{|c|}{ APLIKASI BISNIS II } \\
\hline & & Pengguna & Pengembang & Pengguna & Pengembang \\
\hline LOI masing-masing karakter & 6 & 0.91 & 0.69 & 0.75 & 0.62 \\
\hline LOI masing-masing sub-karakteristik Usability & 8 & 0.95 & 0.83 & 0.80 & 0 \\
\hline LOI masing-masing sub-karakteristik Portability & 4 & 0 & 0.45 & 0 & 0 \\
\hline LOI masing-masing sub-karakteristik Maintainability & 5 & - & 0.69 & - & 0.53 \\
\hline LOI masing-masing sub-karakteristik Efficiency & 2 & 0 & - & 0.16 & - \\
\hline LOI masing-masing sub-karakteristik Reliability & 2 & 0 & - & 0.26 & - \\
\hline LOI masing-masing sub-karakteristik Functionality & 4 & 0.57 & - & 0.81 & - \\
\hline LOI masing-masing sub-karakteristik Traceability & 1 & - & - & 0 & - \\
\hline
\end{tabular}

Karakteristik Traceability dimiliki oleh aplikasi bisnis kedua saja. Hal ini dikarenakan pada kebutuhan pengguna yang digunakan sebagai dasar pembuatan kuisioner terdapat pernyataan yang menyiratkan karakteristik ini. Sedangkan pada aplikasi bisnis pertama tidak terdapat kebutuhan yang bersifat dari karakteristik tersebut.

Pada Tabel 9, analisis dilakukan terhadap nilai reliabel dari kuisioner yang telah dilakukan dengan menggunakan analisis Cronbach Alpha. Pada penilaian ini dilakukan pada dua level yang berbeda, yaitu level pertama pada masing-masing karakteristik dan level kedua pada masing-masing sub karakteristik dari karakteristik level pertama. Pada koefisien Cronbach Alpha yang tidak memiliki nilai, hal ini disebabkan karena tidak adanya pernyataan yang terdapat pada kuisioner yang dibuat. Sedangkan koefisien yang bernilai 0 dikarenakan hanya 
ada satu pernyataan yang merepresentasikan karakteristik tersebut. Akan tetapi pada Tabel 9 terdapat perbedaan pada kolom yang berwarna. Pada kolom yang berwarna abu-abu adalah kolom koefisien sub karakteristik Efficiency dan Reliability pada aplikasi bisnis pertama dengan responden pengguna dan juga kolom koefisien sub karakteristik Usability dan Portability pada aplikasi bisnis kedua dengan responden pengembang. Terlihat nilai koefisien pada keempat kolom tersebut adalah 0 , tetapi hal ini bukan disebabkan oleh hanya ada satu pernyataan yang terdapat pada kuisioner tetapi adalah nilai 0 yang dihasilkan pada perhitungan variance $(\sigma)$. Pada perhitungan koefisien Cronbach Alpha, nilai variance dari masing-masing pernyataan sangat berpengaruh pada nilai koefisien yang dihasilkan.

Hasil koefisien pada masing-masing karakteristik memiliki nilai yang cukup besar baik pada aplikasi bisnis pertama dan kedua dan juga pada responden pengguna dan juga pengembang, yakni 0.91 (91\%), 0.69 (69\%), 0.75 (75\%) dan 0.62 (62\%). Sehingga dapat dikatakan bahwa nilai reliabel dari survei ini pada level pertama (tingkat karakteristik) memiliki nilai yang cukup bagus. Sedangkan pada level yang lebih rendah, nilai koefisien yang dihasilkan tidak teratur, nilai terendah yang dihasilkan adalah 0.26 (26\%) dan yang tertinggi adalah 0.95 (95\%). Hasil yang tidak beraturan ini, menandakan bahwa kuisioner yang dibuat tidak reliabel pada nilai pengujian level kedua (sub karakteristik).

\section{Kesimpulan}

Dalam pengujian suatu kualitas perangkat lunak, pelibatan konsentrasi pengembang penting untuk diperhatikan dalam menentukan kualitas suatu perangkat lunak, selain dengan mengutamakan kebutuhan pengguna. Sehingga analisis terhadap kebutuhan pengguna dan juga konsentrasi pengembang selama proses pengembangan dapat memunculkan karakteristik kualitas baru yang belum tercakup dalam model kualitas perangkat lunak yang telah ada. Selain itu dengan melibatkan konsentrasi pengembang dapat menghasilkan karakteristik yang tidak muncul dalam pelibatan kebutuhan pengguna saja.

Dengan menerapkan proses kerangka kerja yang diajukan, menunjukkan hasil bahwa proses kerangka kerja tersebut dapat digunakan dengan baik untuk melakukan penyesuaian model kualitas perangkat lunak tertentu yakni aplikasi bisnis. Proses kerangka kerja ini dapat digunakan untuk melakukan penyesuaian karakteristik pada level pertama yakni pada tingkatan karakteristik dengan baik.

Dengan proses kerangka kerja ini, juga dapat ditemukan karakteristik-karakteristik utama dalam suatu aplikasi bisnis. Sehingga dalam proses pengujian perangkat lunak tersebut, dapat dilakukan penyesuaian terhadap model kualitas yang digunakan sebagai acuan dan juga karakteristik-karakteristik lain yang sesuai dengan perangkat lunak tersebut.

\section{Referensi}

Al-Qutaish, R. E. 2009. An Investigation of the Weaknesses of the ISO 9126 International Standard. Second International Conference on Computer and Electrical Engineering.

Behkamal, B., Kahani, M., Akbari, \& Year, M.K. 2009. Customizing ISO 9126 Quality Model for Evaluation of B2B Applications. Information and Software Technology, Vol. 599609.

Parwita, W. G. \& Ayu Luh, A. 2012. Komponen Penilaian Kualitas Perangkat Lunak Berdasarkan Software Quality Models. Seminar Nasional Teknologi Informasi \& Komunikasi Terapan 2012 (Semantik 2012).

Nabil, D., Mosad, A., \& Hesham, A.H. 2011. Web-Based Applications Quality Factors: A Survey and a Proposed Conceptual Model. Egyptian Informatics Journal, Vol. 12, p. 211-217.

Sibisi, M., \& Van Waveren, C. C. 2007. A Process Framework for Customizing Software Quality Models. AFRICON 2007.

Suma. V., Shubhamangala, B.R., \& Manjunatha, R. 2013. Customization of Quality Models in Software Projects to Enhance the Business Value. Advance Computing Conference (IACC), 2013 IEEE 3rd International, IEEE 2013, p. 1479-1485. 